\title{
ANALISIS KESALAHAN KONEKSI MATEMATIS SISWA DALAM MENYELESAIKAN MASALAH KONTEKSTUAL DITINJAU DARI KEMAMPUAN MATEMATIS SISWA
}

\author{
Retno Wati ${ }^{1}$, Yoga Dwi Windy Kusuma Ningtyas ${ }^{2}$ \\ FKIP Universitas Muhammadiyah Jember ${ }^{1,2}$ \\ retno.refaerda96@gmail.com¹, kusumaningtyas.dwi@unmuhjember.ac.id ${ }^{2}$
}

\begin{abstract}
Abstrak
Koneksi matematis adalah kemampuan siswa dalam menghubungkan atau mengaitkan ide-ide matematis dengan suatu konsep matematika, antar topik pada materi matematika, antar konsep matematika dengan bidang studi lain dan dengan kehidupan sehari-hari. Penelitian ini bertujuan untuk mendiskripsikan kesalahan koneksi matematis siswa dalam menyelesaikan masalah kontekstual ditinjau dari kemampuan matematis siswa. Subjek penelitian yaitu 3 siswa kelas VIII B SMPI Roudlotul Ulum Randuagung yang berkemampuan tinggi, sedang, dan rendah. Metode pengumpulan data yang digunakan adalah metode tes, wawancara, dan dokumentasi. Hasil analisis data menunjukkan siswa berkemampuan matematis tinggi melakukan kesalahan koneksi matematis yaitu tidak menentukan nilai diameter menggunakan operasi hitung aljabar secara sistematis, kesalahan prosedural. Siswa berkemampuan matematis sedang melakukan kesalahan koneksi matematis yaitu tidak menuliskan prosedur yang sesuai dengan konsep keliling lingkaran , tidak dapat menentukan banyak lampu menggunakan konsep perbandingan, salah menggunakan prosedur yang sesuai dengan konsep, salah menggunakan konsep, tidak mampu membuat model, kesalahan operasi hitung, salah mensubstitusikan nilai variabel, kesalahan prosedural. Siswa berkemampuan matematis rendah melakukan kesalahan koneksi matematis yaitu tidak menuliskan prosedur yang sesuai untuk mencari keliling lingkaran, tidak dapat menentukan jari-jari lingkaran menggunakan operasi hitung aljabar secara sistematis, tidak dapat menentukan banyak lampu menggunakan konsep perbandingan, salah mensubstitusikan nilai variabel, salah menggunakan konsep, kesalahan operasi hitung, asal dalam menjawab, tidak mampu membuat model, kesalahan prosedural.
\end{abstract}

Kata kunci: koneksi matematis, masalah kontekstual, kemampuan matematis.

\begin{abstract}
Mathematical connection is the ability of students in connecting or linking mathematical ideas with a mathematical concept, inter-topic on mathematical material, between mathematical concepts with other fields of study and daily life. This study aims to describe students 'mathematical connection errors in solving contextual problems in terms of students' mathematical abilities. The subjects were 3 students of grade VIII B SMPI Roudlotul Ulum Randuagung with high ability, moderate, and low. Data collection methods used are test methods, interviews, and documentation. The result of the data analysis shows that students with high mathematical ability to make mistake of mathematical connection that does not determine the value of diameter using algebraic counting operation systematically, procedural error. Students with mathematical ability are making a mistake of mathematical connection that is not writing procedure according to circle concept, can not determine many lights using the concept of comparison, incorrect use of procedures in accordance with the concept, incorrect use of concept, unable to create models, miscalculation operation, substituting the wrong value of variables, procedural errors. Students with low mathematical ability to make a mathematical connection error that is not write the appropriate procedure to search the circumference of the circle, can not determine
\end{abstract}


the radius of a circle using algebraic counting operation systematically, can not determine many lights using the concept of comparison, substituting the wrong value of variables, miscalculation operation, origin in replay, unable to create model, procedural error.

Keywords: mathematical connection, contextual problem, mathematical ability.

\section{PENDAHULUAN}

Matematika merupakan salah satu mata pelajaran wajib yang diajarkan pada setiap jenjang pendidikan formal, mulai dari pendidikan di sekolah tk (prekindergarten) hingga ke jenjang perguruan tinggi. Masykur dan Fathani [1] menyatakan bahwa pada pembelajaran matematika yang ditetapkan oleh NCTM memutuskan, bahwa dalam mempelajari matematika siswa memerlukan pemahaman dan aktif dalam membuat pengetahuan baru dari pengalaman dan pengetahuan yang telah mereka miliki sebelumnya. National Council of Teacher of Mathematics [2] menetapkan lima standar proses kemampuan matematis dalam pembelajaran matematika, antara lain: pemecahan masalah, pemahaman dan bukti, komunikasi, koneksi/hubungan, dan penyajian/representasi. Sehingga dapat disimpulkan bahwa, koneksi matematis termasuk dalam salah satu dari standar proses yang harus dicapai oleh siswa dalam pembelajaran matematika

Koneksi dalam pembelajaran matematika berarti hubungan atau keterkaitan antar konsep matematika. Seorang siswa akan memiliki pemahaman secara mendalam dan mampu bertahan lebih lama, apabila siswa tersebut dapat mengaitkan konsep-konsep matematika secara matematis, karena kemampuan siswa tersebut dapat melihat adanya keterkaitan anatara ide-ide matematis dalam matematika, antar-konteks dengan topik matematis, dan dengan pengalaman pada kehidupan sehari-hari [2]. Jadi, koneksi matematis adalah kemampuan siswa dalam menghubungkan atau mengaitkan ide-ide matematis dengan suatu konsep matematika, antara berbagai topik pada materi matematika, dan antar konsep matematika dengan bidang studi lain serta dengan kehidupan sehari-hari.

Dalam proses pembelajaran matematika, meski guru sudah melibatkan koneksi matematis masih terdapat beberapa siswa yang mengalami kesulitan koneksi matematis dalam menyelesaikan suatu masalah matematika. Menurut Bahr dan Garcia [3] menyatakan bahwa, kesulitan koneksi matematis siswa adalah suatu hambatan yang dihadapi siswa dalam menyelesaikan soal yang disebabkan siswa mengalami kesulitan dalam menghubungkan antara berbagai representasi matemais serta konsep matematik secara internal ataupun secara eksternal. Adanya kesulitan tersebut dapat dilihat pada kesalahan siswa dalam menuliskan prosedur atau langkah-langkah dalam menyelesaikan masalah matematika. Dengan demikian, guru harus mengetahui seberapa besar kemampuan koneksi matematis yang dimiliki oleh siswa serta membantu untuk melatih dan membangun kemampuan koneksi matematis siswa.

Salah satu kegiatan yang dapat dilakukan untuk membangun dan melatih koneksi matematis yaitu kegiatan penyelesaian masalah kontekstual. Kegiatan penyelesaian masalah kontekstual adalah suatu kegiatan yang mempermudah siswa dalam menemukan suatu hubungan atau keterkaitan dari berbagai konsep dalam matematika serta mampu menerapkannya dalam kehidupan sehari-hari [4].

Masalah kontekstual adalah masalah yang memiliki konteks, dimana suatu permasalahan tersebut dikaitkan dengan konsep-konsep abstrak matematika dan 
kehidupan sehari-hari. Penggunaan konteks dalam suatu proses pembelajaran matematika di kelas, menjadikan konsep-konsep abstrak matematika menjadi lebih mudah dipahami dan dimengerti oleh siswa melalui pemahaman yang mereka bentuk dari situasi nyata yang telah dikenal dengan baik oleh siswa itu sendiri [5].

Dalam menyelesaikan masalah kontekstual, siswa membutuhkan kemampuan matematis. Kemampuan matematis adalah kemampuan dan keterampilan dasar yang dimiliki siswa dalam pembelajaran matematika. Pada penelitian ini, kemampuan matematis yang dimaksud adalah tingkat kemampuan matematis siswa yang dikategorikan pada tiga tingkatan yaitu tinggi, sedang, dan rendah.

Pada penelitian pendahuluan yang telah dilakukan oleh peneliti di lokasi penelitian, ditemukan fakta adanya kesalahan koneksi matematis siswa kelas VIII SMPI Roudlotul Ulum Randuagung dalam menyelesaikan soal pada materi lingkaran. Siswa mengalami kesalahan dalam mensubstitusikan angka sesuai dengan konsep yang ditulisnya. Siswa terbalik dalam menentukan rumus keliling dan luas lingkaran. Berdasarkan fakta tersebut, maka penelitian tentang kesalahan koneksi matematis ini dilaksanakan dengan tujuan untuk mendiskripsikan kesalahan koneksi matematis siswa dalam menyelesaikan masalah kontekstual ditinjau dari kemampuan matematis siswa.

\section{METODE}

Penelitian ini menggunakan penelitian kualitatif-deskriptif dengan tujuan mendiskripsikan tentang kesalahan koneksi matematis yang dilakukan siswa dalam menyelesaikan masalah kontekstual ditinjau dari kemampuan matematis siswa. Subjek penelitian yaitu 3 siswa kelas VIII B SMPI Roudlotul Ulum Randuagung yang berkemampuan matematis tinggi, sedang, dan rendah masing-masing satu siswa. Subjek penelitian dipilih berdasarkan pengkategorian tingkat kemampuan matematis siswa dari nilai UTS genap 2017/2018 serta berdasarkan usulan guru mata pelajaran matematika kelas VIII.

Data penelitian diperoleh melalui hasil tes dan hasil wawancara dengan subjek penelitian. Instrumen utama pada penelitian kualitatif adalah peneliti itu sendiri. Selain itu, terdapat instrumen pendukung berupa soal tes dan pedoman wawancara. Soal tes yang diberikan berjumlah tiga soal pada materi lingkaran mengenai luas dan keliling lingkaran. Pertanyaan yang disusun dalam pedoman wawancara berisi poin-poin penting saja, sementara pada saat wawancara berlangsung pertanyaan yang telah disusun bisa mengembang atau mengerucut, guna menggali dan memperoleh data ataupun informasi yang mungkin tidak dapat diperoleh dari hasil tes. Sebelum digunakan, soal tes dan pedoman wawancara dikonsultasikan dengan dosen pembimbing kemudian divalidasi oleh dua dosen ahli pendidikan matematika dan guru mata pelajaran matematika kelas VIII di SMPI Roudlotul Ulum Randuagung. Setelah dinyatakan valid, soal tes dan pedoman wawancara dapat digunakan.

Analisis data yang digunakan adalah analisis data menurut Miles dan Huberman [6] yang meliputi reduksi data, penyajian data, dan kesimpulan. Sedangkan teknik keabsahan data yang digunakan yaitu meningkatkan ketekunan, triangulasi, diskusi dengan teman sejawat, dan menggunakan bahan referensi. Triangulasi yang digunakan pada penelitian ini adalah triangulasi teknik. 


\section{HASIL DAN PEMBAHASAN}

Sebelum dilaksanakan penelitian, peneliti terlebih dahulu meminta izin kepada kepala sekolah SMPI Roudlotul Ulum Randuagung dan menentukan subjek penelitian. Setelah subjek penelitian didapatkan, selanjutnya pelaksanaan tes dan wawancara. Selanjutnya data yang diperoleh dianalisis. Berdasarkan hasil tes subjek penelitian, pada soal tes nomor 1 dari tiga subjek penelitian hanya 2 siswa yang dapat menyelesaikan soal. Pada soal nomor 2 hanya 1 siswa yang dapat menyelesaikan soal. Sedangkan pada soal nomor 3 semua subjek penelitian tidak dapat menyelesaikan soal. Adapun soal beserta penyelesaiannya dari salah satu siswa yang melakukan kesalahan koneksi matematis yaitu sebagai berikut:

1) Amir mempunyai kolam ikan yang berbentuk lingkaran. Jika luas kolam sama dengan $1.256 \mathrm{~m}^{2}$. Tentukan diameter kolam tersebut $(\pi=3,14)$.

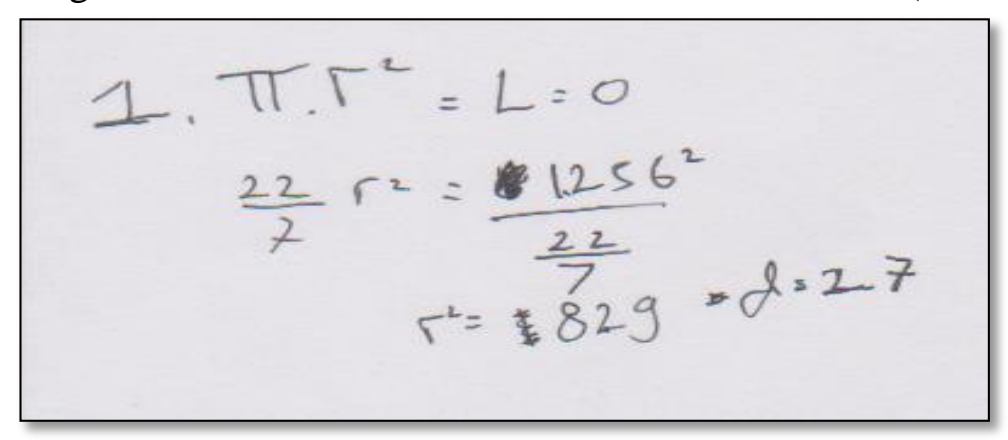

GAMBAR 1. Penyelesaian Siswa Pada Soal Nomor 1

2) Sebuah taman berbentuk lingkaran dengan jari-jari $14 \mathrm{~m}$. Di sekeliling taman akan dipasang lampu, dengan jarak 8 meter. Berapa banyak lampu yang diperlukan?

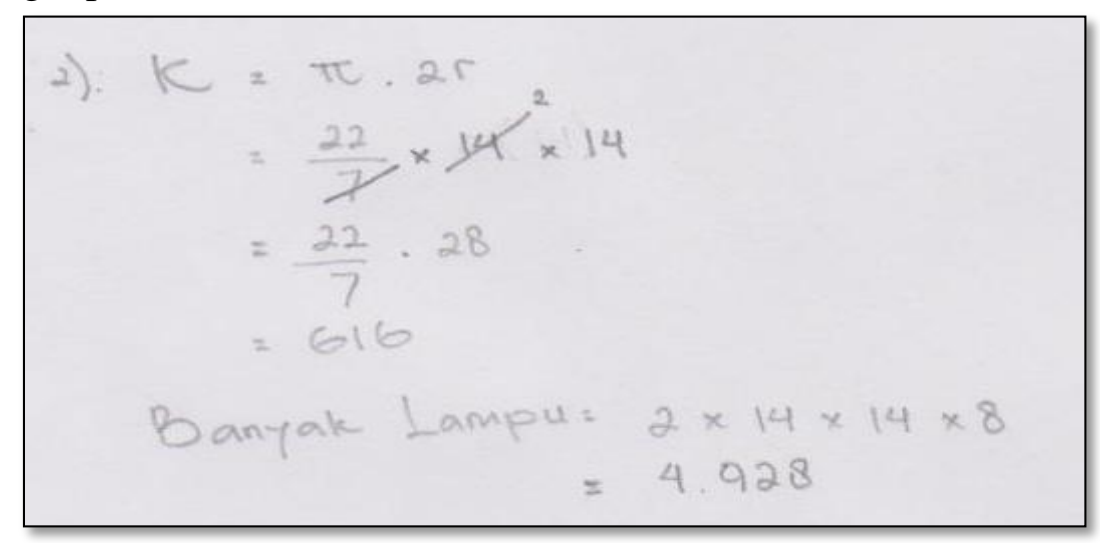

Gambar 2. Penyelesaian Siswa Pada Soal Nomor 2

3) Pak Adi mempunyai sebidang tanah berbentuk persegi dengan luas $400 \mathrm{~cm}^{2}$. Bidang tersebut akan digunakan untuk membuat kolam berbentuk lingkaran dengan diameter kolam sama dengan panjang sisi tanah. Hitunglah luas dan keliling dari sisa bidang tanah tersebut! 


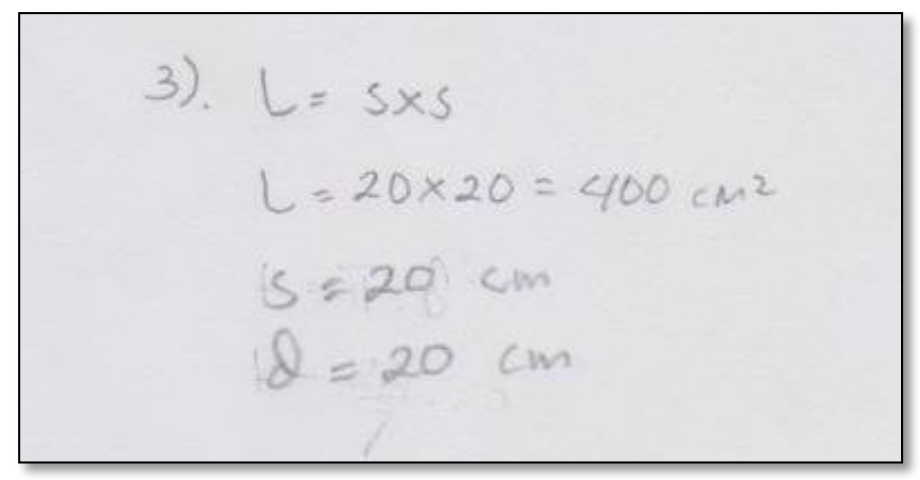

GAMBAR 3. Penyelesaian Siswa Pada Soal Nomor 3

Berikut adalah kesalahan koneksi matematis yang dilakukan oleh siswa dalam menyelesaikan masalah kontekstual ditinjau dari kemampuan matematis siswa.

\section{Kesalahan Koneksi Matematis Siswa dalam Menyelesaikan Masalah Kontekstual oleh Subjek dengan Kemampuan Matematis Tinggi (KMT)}

Subjek KMT melakukan kesalahan koneksi matematis pada soal nomor 3 yaitu pada aspek koneksi topik antar-materi dalam matematika yaitu KMT tidak menentukan nilai diameter menggunakan operasi hitung aljabar secara sistematis. KMT menentukan nilai diameter dengan cara mengalikan sebuah bilangan yang hasilnya sama dengan nilai luas persegi. Dimana panjang diameter sama dengan panjang sisi persegi. KMT menggunakan cara coba-coba (trial and error).

Pada aspek koneksi matematika dengan dunia nyata atau kehidupan seharihari yaitu KMT tidak memilih strategi dan aturan yang sesuai untuk menyelesaikan masalah, dimana KMT tidak menuliskan prosedur yang sesuai untuk menyelesaikan masalah (kesalahan prosedural). Dari hasil pengerjaan tes dan hasil wawancara dapat disimpulkan bahwa KMT tidak dapat melajutkan penyelesaian soal karena tidak menguasai prosedural untuk menyelesaikan soal. KMT hanya menyelesaikan soal pada menentukan nilai diameter dari luas persegi yang diketahui pada soal. Berdasarkan hasil penelitian Natsir [7] salah satu kesalahan prosedural yang dilakukan oleh siswa yaitu siswa tidak menyelesaikan pengerjaan soal atau siswa tidak mengerti permintaan soal biasanya hanya menuliskan jawabannya sampai hal apa yang diketahui saja.

\section{Kesalahan Koneksi Matematis Siswa dalam Menyelesaikan Masalah Kontekstual oleh Subjek dengan Kemampuan Matematis Sedang (KMS)}

Subjek KMS melakukan kesalahan koneksi matematis pada aspek koneksi antar-topik dalam satu materi yaitu pada soal nomor 2. KMS tidak menuliskan prosedur yang sesuai dengan konsep keliling lingkaran. KMS telah menuliskan rumus keliling lingkaran dengan benar, yaitu keliling lingkaran $=\pi \times 2 r$. Namun, pada saaat mensubstitusikan angka siswa mengikuti prosedur dari konsep luas lingkaran. Kesalahan prosedur ini dapat disebabkan karena KMS kurang teliti dalam mengerjakan.

Pada aspek koneksi topik antar-materi dalam matematika yaitu pada soal nomor 2. KMS tidak dapat menentukan banyak lampu menggunakan konsep perbandingan. KMS mencari banyaknya lampu dengan caranya sendiri yaitu $2 \times$ $14 \times 14 \times 8$. Ketika ditanyakan alasannya, KMS menjawab bahwa dia tidak bisa. 
Hal ini menunujukkan bahwa KMS melakukan kesalahan koneksi dalam menghubungkan konsep-konsep atau topik-topik antar-materi dalam lingkaran dengan perbandingan.

Pada aspek koneksi matematika dengan dunia nyata atau kehidupan seharihari yaitu KMS melakukan kesalahan koneksi matematis dalam memilih strategi dan aturan yang sesuai dalam menyelesaikan masalah yaitu pada soal nomor 2 dan 3. Pada soal nomor 2, KMS melakukan kesalahan dalam menggunakan prosedur dan konsep yang sesuai. Kesalahan menggunakan prosedur yang sesuai yaitu KMS tidak menuliskan prosedur yang sesuai dengan konsep keliling yang telah ditulisnya. Sedangkan untuk kesalahan menggunakan konsep yaitu kesalahan KMS dalam menggunakan konsep dalam menentukan banyaknnya lampu.

Pada soal nomor 3, KMS melakukan kesalahan koneksi matematis yaitu dalam membuat model, melakukan operasi hitung, mensubstitusikan nilai variabel dan kesalahan prosedural. Pertama kesalahan dalam membuat model, yaitu KMS tidak memahami bahwa nilai jari-jari atau diameter dapat dicari dari luas persegi yang telah diketahui dari soal. Dari hasil penelitian Ardiyanti [8] menyatakan bahwa salah satu kesalahan pada aspek membuat model matematika yaitu siswa salah menuliskan informasi yang terdapat pada soal ke dalam kalimat (model) matematika.

Kedua, kesalahan dalam melakukan operasi hitung. KMS melakukan kesalahan operasi perhitungan dalam menentukan luas lingkaran. Kesalahan ini dapat disebabkan karena KMS kurang menguasai langkah-langkah atau konsep operasi hitung bilangan desimal, dimana nilai $\pi$ yang digunakan oleh KMS adalah 3,14. Sejalan dengan hasil penelitian Ramdhani [9] bahwa siswa dengan kemampuan matematis sedang tidak dapat mengoperasikan langkah-langkah atau konsep-konsep yang digunakan dalam menyelesaikan soal.

Ketiga, kesalahan menuliskan prosedur yang sesuai dalam menyelesaikan masalah (kesalahan prosedural). Pada soal nomor 3 tersebut nilai jari-jari atau diameter lingkaran belum diketahui. Namun, KMS secara langsung menuliskan luas lingkaran yang dicari. Hal ini sesuai dengan pendapat Natsir [7] bahwa kesalahan prosedural adalah kesalahan dalam penyusunan langkah-langkah penyelesaian soal, salah satunya siswa tidak menyelesaikan soal dengan langkahlangkah penyelesaian yang benar.

Keempat, kesalahan dalam mensubstitusikan nilai variabel. Dalam menghitung nilai luas lingkaran, KMS salah mensubstitusikan nilai jari-jari. Hal ini dikarenakan KMS tidak terlebih dahulu mencari nilai diameter. Karena pada soal telah diketahui bahwa panjang diameter sama dengan panjang sisi persegi dan luas persegi sudah diketahui pada soal.

\section{Kesalahan Koneksi Matematis Siswa dalam Menyelesaikan Masalah Kontekstual oleh Subjek dengan Kemampuan Matematis Rendah (KMR)}

Subjek KMR melakukan kesalahan koneksi matematis pada aspek koneksi antar-topik dalam satu materi yaitu pada soal nomor 2. KMR tidak menggunakan prosedur yang sesuai untuk mencari keliling lingkaran. Dari hasil wawancara, KMR memahami bahwa yang harus dicari adalah keliling taman yang berbentuk lingkaran. Tetapi prosedur atau rumus yang dituliskan adalah prosedur dari luas lingkaran. Dapat disimpulkan bahwa siswa dengan kemampuan matematis rendah tidak dapat menghubungkan topik-topik dalam satu materi. 
Pada aspek koneksi topik antar-materi dalam matematika KMR melakukan kesalahan koneksi matematis dalam menuliskan prosedur yang sesuai dengan topik antar-materi matematika yaitu soal nomor 1 dan 2. Pada soal nomor 1, KMR tidak dapat menentukan jari-jari lingkaran menggunakan operasi hitung aljabar. Prosedur atau langkah yang dilakukan oleh KMR kurang tepat dan tidak runtut. Pada soal nomor 2, kesalahan koneksi matematis yang dilakukan oleh KMR yaitu dalam menghubungkan dan menuliskan prosedur yang sesuai dengan topik-topik yang sesuai antar-materi yang berkaitan. KMR tidak dapat menentukan banyak lampu di taman menggunakan konsep perbandingan.

Pada aspek koneksi matematika dengan dunia nyata atau kehidupan seharihari yaitu pada soal nomor 1, 2,dan 3. Pada soal nomor 1, KMR melakukan kesalahan koneksi dalam mensubstitusikan nilai variabel. Nilai variabel yang dimaksud adalah nilai phi. KMR tidak menggunakan nilai phi yang diketahui pada soal, yaitu $\pi=3,14$ tetapi KMR menggunakan nilai phi $\pi=\frac{22}{7}$. Ketika diwawancara, KMR menjelaskan bahwa dia hanya mengikuti apa yang dicatat dibuku.

Pada soal nomor 2, kesalahan koneksi matematis yang dilakukan oleh KMR, antara lain dalam (1) membuat model matematika, yaitu KMR tidak dapat mebuat model matematika. KMR tidak dapat memanfaatkan informasi yang terdapat dalam soal, bahwa taman berbentuk lingkaran dan lampu akan dipasang di sekeliling taman; (2) menggunakan konsep matematika, yaitu KMR tidak dapat menggunakan konsep matematika. Hal tersebut terlihat dari hasil pengerjaan KMR yang menggunakan konsep luas lingkaran dalam menyelesaikan masalah dalam soal nomor 2, dimana seharusnya KMR menggunakan konsep keliling lingkaran; (3) melakukan operasi hitung, yaitu pada langkah kedua KMR menuliskan 3,14 $\times$ $14 \times 14$, tetapi langkah ketiga KMR menuliskan 3,14 $\times 7 \times 8$; (4) asal menjawab, yaitu ketika menentukan nilai banyaknya lampu. KMR tidak menuliskan prosedur atau rumus dalam menentukan banyak lampu. KMR hanya menuliskan hasilnya saja.

Pada soal nomor 3, kesalahan koneksi matematis yang dilakukan oleh KMR yaitu, pertama kesalahan dalam membuat model matematika. KMR tidak memahami bahwa nilai jari-jari atau diameter dapat dicari dari luas persegi yang telah diketahui dari soal. Kedua, kesalahan prosedural yaitu KMR secara langsung menentukan nilai luas dan keliling lingkaran sedangkan nilai jari-jari atau diameter tidak ditentukan terlebih dahulu. Padahal sebelum menentukan nilai dari luas ataupun keliling lingkaran, siswa terlebih dahulu mencari nilai dari jari-jari ataupun diameter lingkaran.

Berdasarkan uraian kesalahan koneksi matematis yang dilakukan oleh KMR pada soal nomor 3, dapat disimpulkan bahwa KMR kurang mampu dalam mengaitkan konsep-konsep matematika untuk menyusun sebuah penyelesaian masalah kontekstual. Hasil penelitian Widarti [5] menyimpulkan bahwa subjek berkemampuan rendah tidak bisa mengaitkan masalah dengan konsep matematika, serta tidak bisa memperluas ide-ide matematikanya dalam menyelesaikan masalah.

\section{KESIMPULAN}

Berdasarkan penelitian yang telah dilaksanakan dan data yang telah diperoleh, maka peneliti menyimpulkan: 
a. Kesalahan koneksi matematis subjek dengan kemampuan matematis tinggi antara lain kesalahan dalam: (1)koneksi topik antar-materi dalam matematika, yaitu tidak menentukan nilai diameter menggunakan operasi hitung aljabar secara sistematis; (2)koneksi matematika dengan dunia nyata atau kehidupan sehari-hari, yaitu kesalahan prosedural.

b. Kesalahan koneksi matematis subjek dengan kemampuan matematis sedang antara lain kesalahan dalam: (1)koneksi antar-topik dalam satu materi, yaitu tidak menuliskan prosedur yang sesuai dengan konsep keliling lingkaran; (2)koneksi topik antar-materi dalam matematika, yaitu tidak dapat menentukan banyak lampu menggunakan konsep perbandingan; (3)koneksi matematika dengan dunia nyata atau kehidupan sehari-hari, yaitu salah menggunakan prosedur yang sesuai dengan konsep, salah menggunakan konsep, tidak mampu membuat model, kesalahan operasi hitung, salah mensubstitusikan nilai variabel, dan kesalahan prosedural.

c. Kesalahan koneksi matematis subjek dengan kemampuan matematis rendah antara lain kesalahan dalam: (1)koneksi antar-topik dalam satu materi, yaitu tidak menuliskan prosedur yang sesuai untuk mencari keliling lingkaran; (2)koneksi topik antar-materi dalam matematika, yaitu tidak dapat menentukan jari-jari lingkaran menggunakan operasi hitung aljabar secara sistematis, tidak dapat menentukan banyak lampu di taman menggunakan konsep perbandingan; (3)koneksi matematika dengan dunia nyata atau kehidupan sehari-hari, yaitu salah mensubstitusikan nilai variabel, salah menggunakan konsep, kesalahan operasi hitung, asal dalam menjawab, tidak mampu membuat model, dan kesalahan prosedural.

Saran yang dapat diberikan dari hasil penelitian ini adalah kepada peneliti lanjutan disarankan jika hendak melakukan penelitian kualitatif yang sama tentang koneksi matematis dalam menyelesaikan masalah kontekstual hendaknya tambahkan atau gunakan tahap-tahap penyelesaian masalah agar lebih mudah dalam menganalisis data hasil pengerjaan siswa. Dan waktu pelaksanaan wawancara peneliti harus lebih teliti dan cermat dalam menanyakan hal-hal yang perlu dimintai penjelasan dari subjek penelitian.

\section{DAFTAR RUJUKAN}

[1] Masykur, M., \& Fathani, A. H. 2017. Mathematical Intelligence Cara Cerdas Melatih Otak dan Menanggulangi Kesulitan Belajar. Jogjakarta: Ar-Ruzz Media.

[2] NCTM. 2000. Principles and Standards for School Mathematics. US: National Council of Teachers of Mathematics.

[3] Rahayu, A. M., Irawan, E. B., \& Susiswo. 2016. Analisis Kesalahan Koneksi Matematis Siswa dalam Menyelesaikan Masalah Materi Bangun Datar Segiempat. Universitas Kanjuruhan Malang: Prosisding Seminar Nasional Pendidikan Matematika. Vol. 1.

[4] Pitriani, R., \& Afriansyah, E. A. 2016. Persepsi dalam Pembelajaran Pendekatan Keterampilan Proses Terhadap Kemampuan Koneksi Matematis Siswa. Jurnal Gantang Pendidikan Matematika FKIP - UMRAH, (Online), Vol. 1, No. 2, (http://ojs.umrah.ac.id, diakses 13 Maret 2018).

[5] Widarti, A. 2013. Kemampuan Koneksi Matematis dalam Menyelesaikan Masalah Kontekstual Ditinjau dari Kemampuan matematis Siswa. Skripsi tidak diterbitkan. Jombang: STKIP PGRI Jombang.

[6] Sugiyono. 2013. Metode Penelitian Pendidikan Pendekatan Kuantitatif, Kualitatif dan R \& D. Bandung: Alfabeta.

[7] Natsir, N., Tandiayuk, M. B., \& Karniman, T. S. 2016. Profil Kesalahan Konseptual dan Prosedural Siswa dalam Menyelesaikan Soal Cerita Himpunan Di Kelas VII SMPN 1 
Siniu. Jurnal Elektronik Pendidikan Matematika Tadulako, (Online) Vol. 3, No. 4, (http://jurnal.untad.ac.id/jurnal/index.php/JEPMT/article/view/7230, diakses 14 Mei 2018).

[8] Ardiyanti, H. B., \& Yunarti, T. 2014. Analisis Kesalahan Siswa dalam Menyelesaikan Soal Cerita Matematika. Jurnal Pendidikan Matematika Unila, (Online), Vol. 2, No. 7, (http://jurnal.fkip.unila.ac.id/index.php/MTK/article/view/6590, diakses tanggal 4 Juni 2018).

[9] Ramdhani, M. R., Widiyastuti, E., \& Subekti, F. E. 2016. Analisis Kemampuan Koneksi Matematis Siswa Kelas VII SMP Negeri 1 Kembaran Materi Bangun Datar. Universitas Muhammadiyah Purwokerto: Prosiding Seminar Matematika dan Pendidikan Matematika. 